\title{
Pengaruh Pijat Punggung Terhadap Tekanan Darah Pada Pasien Hipertensi
}

\author{
${ }^{1}$ Ardiansyah*, \\ ${ }^{1}$ Program Studi Ilmu Keperawatan, STIKES Citra Delima Bangka Belitung \\ Email : ansyaha672@gmail.com
}

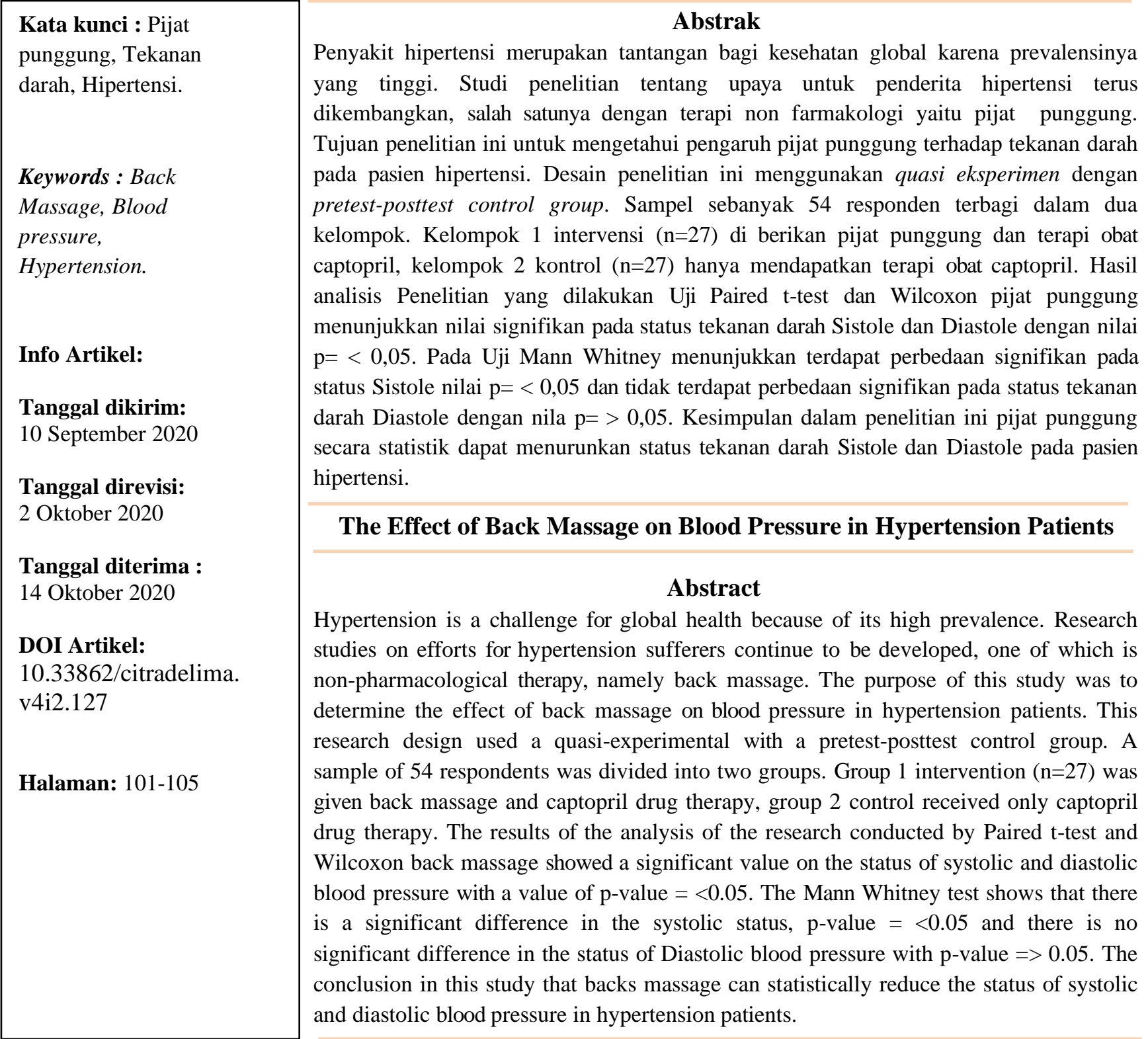




\section{PENDAHULUAN}

WHO memprediksi prevalensi kejadian hipertensi untuk wilayah The South Asian Association For Regional Cooperation (SAARC) nampak lebih tinggi dari 13\% hingga sampai $48 \%$ (Rahman 2015; Neupane 2014).

Data Riskesdas melaporkan pada tahun 2013, prevalensi kejadian hipertensi di Indonesia dari umur 18 tahun ke atas sebesar $25,8 \%$ dan dari 15 juta yang menderita hipertensi 50\% lainnya belum terkendali (Artiyaningrum and Azam, 2016).

Hipertensi yang tidak di kontrol akan menyebabkan komplikasi seperti gagal ginjal, stroke, dan koroner. Faktor-faktor yang memicu terjadinya hipertensi salah satunya faktor genetik, jenis kelamin, stress, kurangnya berolahraga, serta mengkonsumsi garam yang berlebih, dan merokok (Nuraini,2015).

Upaya yang di lakukan penderita hipertensi untuk menurunkan tekanan darah dapat diterapkan dengan dua cara yaitu secara non farmakologi dan farmakologi. Terapi farmakologi ini dengan menggunakan obat anti hipertensi, dan juga untuk terapi non farmakologi dapat melakukan dengan berbagai upaya salah satunya dengan pijat. Pijat punggung dapat melancarkan sirkulasi aliran darah, serta melemaskan ketegangan otot. Beberapa penelitian telah membuktikan bahwa metode pijat dapat menurunkan tekanan darah pada penderita hipertensi berat maupun sedang. Secara fisiologi pijat dapat mempengaruhi tubuh secara fisik maupun psikis. Pijat dapat memberikan efek relaksasi dengan menstimulasi mengeluarkan endofrin pada otak sehingga berefek pada saraf simpatis dan menstimulasi saraf parasimpatis, serta merangsang otot metabolisme pada sirkulasi darah (Zunaidi, Nurhayati and Prihatin, 2016).

Penelitian terapi pijat punggung pada penderita hipertensi menemukan bahwa pijat dapat memiliki hasil dan berefek positif dapat menurunkan tekanan darah (Helena 2015).

Mengingat banyaknya kasus kejadian hipertensi tersebut, maka peneliti tertarik untuk mengetahui bagaimana pengaruh pemberian intervensi pijat punggung sebagai salah satu terapi nonfarmakologis untuk menurunkan tekanan darah pada penderita hipertensi.

Masalah yang dapat dikemukakan dalam penelitian ini adalah "Bagaimana pengaruh pijat punggung terhadap tekanan darah pada pasien yang mengalami hipertensi?". Tujuan penelitian ini adalah menganalisis pengaruh pijat punggung terhadap tekanan darah pada pasien hipertensi.

\section{METODE}

Metode dalam penelitian kuantitatif ini yaitu menggunakan Quasi Experiment, dengan pretestposttest control group design. Jenis intervensi dalam penelitian ini yaitu pijat di area bagian punggung di berikan pada waktu pagi hari, dilakukan oleh peneliti dan asisten peneliti yang sudah memiliki pelatihan sertifikat pijat. Metode yang diberikan menggunakan Teknik menggosok dengan stroke pendek (petrissage), menggosok dengan stroke Panjang (friction), mengeluni (Effleuarge) dan perkusi (Tappotement). Durasi pijat dilakukan selama 20 menit.

Kelompok intervensi dilakukan pijat punggung dan terapi obat captopril dalam satu kali sehari selama 3 hari. Kelompok kontrol hanya mendapatkan terapi obat captopril. Sebelum diberikan intervensi dilakukan pretest terlebih dahulu, setelah itu diberikan intervensi, kemudian dilakukan posttest. selanjutnya diberikan intervensi selama 3 hari berturut-turut dan diakhiri dengan pengukuran tekanan darah ulang.

Populasi dalam penelitian ini yaitu pasien yang menderita hipertensi Di Daerah Wilayah Kerja Puskesmas Petaling Kabupaten Bangka yang rutin berobat atau kontrol ke puskesmas. Jumlah dalam sampel penelitian ini sebanyak 27 responden untuk masing-masing kelompok intervensi dan kelompok kontrol. Pengambilan sampel menggunakan tehnik purposive sampling. Di mana pengambikan atau pemilihan sampel di dasarkan atas sesuai dengan kriteria inklusi : Berjenis kelamin laki-laki, Beragama islam, Usia 35 sampai dengan 60 tahun, Pasien yang rutin rawat jalan minimal 3 bulan di Puskesmas Petaling. kriteria eksklusi : Pasien yang mempunyai penyakit komplikasi (DM dan Gagal ginjal), Pasien yang mempunyai Riwayat gangguan jiwa, Pasien yang memiliki Riwayat penyakit pada tulang belakang, Pasien yang memiliki penyakit kulit di area punggung, Pasien yang tidak mau berpartisipasi.

Alat ukur yang digunakan untuk mengukur tekanan darah dalam penilitian ini adalah Sphygmamonameter digital yang sudah dilakukan uji validitas dan reabilitas. Analisa data untuk mengetahui pengaruh kelompok intervensi peneliti menggunakan uji Paired t-test dan Wilcoxon. Untuk mengetahui perbedaan efek terapi pada ke dua kelompok peneliti menggunakan uji Mann-Whitney. 


\section{HASIL DAN PEMBAHASAN}

Hasil

Tabel 1 karakteristik responden berdasarkan usia, pendidikan, pekerjaan, kebiasaan merokok dan konsumsi alkohol $(\mathrm{n}=54)$.

\begin{tabular}{|c|c|c|c|c|}
\hline \multirow{2}{*}{$\begin{array}{c}\text { Keterangan responden } \\
\text { Variabel }\end{array}$} & \multicolumn{2}{|c|}{ Kel.1 $(n=27)$} & \multicolumn{2}{|c|}{ Kel.2(n=27) } \\
\hline & $f$ & $\%$ & $\mathrm{f}$ & $\%$ \\
\hline \multicolumn{5}{|l|}{ Usia } \\
\hline $35-45$ tahun & 7 & 25,9 & 3 & 11,1 \\
\hline 45-55 tahun & 10 & 37,0 & 10 & 37,0 \\
\hline 55-60 tahun & 10 & 37,0 & 14 & 51,9 \\
\hline \multicolumn{5}{|l|}{ Pendidikan } \\
\hline Tidak sekolah & 3 & 11,1 & 4 & 14,8 \\
\hline SD & 6 & 22,2 & 6 & 22,2 \\
\hline SMP & 6 & 22,2 & 11 & 40,7 \\
\hline SMA & 10 & 37,0 & 6 & 22,2 \\
\hline Perguruan Tinggi & 2 & 7,4 & 0 & 0 \\
\hline \multicolumn{5}{|l|}{ Pekerjaan } \\
\hline Tani & 5 & 18,5 & 3 & 11,1 \\
\hline PNS & 2 & 7,4 & 0 & 0 \\
\hline Swasta & 4 & 14,8 & 8 & 29,6 \\
\hline Wiraswasta & 9 & 33,3 & 10 & 37,0 \\
\hline Buruh & 7 & 25,9 & 6 & 22,2 \\
\hline \multicolumn{5}{|l|}{ Kebiasaan Merokok } \\
\hline Merokok & 8 & 29,6 & 12 & 44,4 \\
\hline Tidak Merokok & 19 & 70,4 & 15 & 55,6 \\
\hline \multicolumn{5}{|l|}{ Konsumsi Alkohol } \\
\hline Tidak Ada & 27 & 100,0 & 27 & 100,0 \\
\hline
\end{tabular}

Keterangan : Kel. 1 Pijat punggung, kel. 2 Kontrol

Tabel 1 menunjukkan sebagian besar usia pada

tiap kelompok mengalami hipertensi berada pada rentang usia 55-60 tahun. Pada variabel pendidikan terlihat perbedaan tiap kelompok, dimana kelompok 1 sebagian besar SMA, dan kelompok 2 pendidikan SMP. Varaibel pekerjaan terlihat tiap kelompok sebagian besar pada tingkat pekerjaan wiraswasta dan buruh. Pada variabel kebiasaan merokok terdapat pada kelompok 1 sebagian besar tidak merokok, kelompok 2 yaitu merokok. Dari ke dua kelompok tersebut dari total 54 responden terdapat semuanya tidak mengkonsumsi alkohol.

Tabel 2 Pengaruh intervensi terhadap tekanan darah pada ke-2 kelompok $(n=54)$

\begin{tabular}{|c|c|c|c|}
\hline Variabel & & $\mathrm{t}$ & P-Value \\
\hline \multicolumn{4}{|c|}{ Kel. $1(n=27)$} \\
\hline Sistole & $\begin{array}{l}\text { Pretest } \\
\text { Posttest }\end{array}$ & 7,351 & $0,001^{*}$ \\
\hline Diastole & $\begin{array}{l}\text { Pretest } \\
\text { Posttest }\end{array}$ & 3,616 & $0,001 * *$ \\
\hline \multicolumn{4}{|c|}{ Kel. $2(n=27)$} \\
\hline Sistole & $\begin{array}{l}\text { Pretest } \\
\text { Posttest }\end{array}$ & 1,134 & $0,257 * *$ \\
\hline Diastole & $\begin{array}{l}\text { Pretest } \\
\text { Posttest }\end{array}$ & 0,035 & $0,972 * *$ \\
\hline
\end{tabular}

Keterangan : kel. 1 Pijat punggung, kel. 2 kontrol. $* \mathrm{p}<0,05$ based on paired t-test, $* * \mathrm{p}<0,05$ based on wilcoxon test.

Berdasarkan tabel 2 pada kelompok 1 hasil Uji paired t-test menunjukkan bahwa nilai $\mathrm{p}<0,05$ pada status tekanan darah Sistole. Hasil Uji Wilcoxon menunjukkan bahwa nilai $\mathrm{p}<0,05$ pada status tekanan darah Diastole. Dapat di simpulkan bahwa intervensi pijat punggung dan dapat menurunkan status tekanan darah Sistole dan Diastole.

Pada kelompok 2 hasil Uji Wilcoxon menunjukkan nilai $\mathrm{p}>0,05$ terhadap status tekanan darah Sistole dan Diastole. Dapat di simpulkan bahwa tidak ada perbedaan terhadap status tekanan darah Sistole dan Diastole pada pasien hipertensi terhadap kelompok kontrol.

Tabel 3 Hasil Uji Mann Whitney status tekanan darah pada ke Dua kelompok $(n=54)$

\begin{tabular}{ll}
\hline Tekanan Darah & P-Value \\
\hline Kel. 1 dengan Kel. 2 & \\
\hline Sistole & 0,007 \\
Diastole & 0,430 \\
\hline
\end{tabular}

Keterangan : Kel. 1 Pijat punggung, Kel. 2 kontrol

Berdasarkan tabel 3 pada kel.1 dengan kel.2 hasil Uji Mann Whitney nilai $\mathrm{p}<0,05$ pada status tekanan darah Sistole. sedangkan pada status tekanan darah Diastole nilai $\mathrm{p}>0,05$. Dapat di simpulkan bahwa terdapat perbedaan nilai signifikan terhadap status tekanan darah pada Sistole, sedangkan pada status tekanan darah Diastole tidak mengalami perbedaan.

\section{PEMBAHASAN}

A. Pengaruh pijat punggung terhadap status tekanan darah pada penderita hipertensi.

Berdasarkan hasil analisa pada tabel 2 di atas pada kelompok 1 menunjukkan nilai $\mathrm{p}<$ 0,05 artinya adanya penurunan secara sginifikan terhadap status tekanan darah Sistole dan Diastole. Dapat di simpulkan bahwa intervensi pijat punggung dapat menurunkan status tekanan darah Sistole dan Diastole.

Hasil tersebut juga di dukung oleh beberapa literatur penelitian yang telah di lakukan sebelumnya bahwa ketika dilakukan pijat pada seseorang dapat menimbulkan respon relaksasi menyeluruh, mencakup keadaan relaksasi secara kognitif, secara behavior dan secara fisiologis lainya, menurunkan kadar epinefrin dan norepinefrin dalam pembuluh darah (Juliantri, Nurfianti, and Maulana 2015).

Hasil penelitian sebelumnya menyatakan bahwa terapi pijat dapat memberikan pengaruh

http://jurnalilmiah.stikescitradelima.ac.id/index.php/JI Vol. 4 No.2 Januari 2021 
terhadap status tekanan darah systole dan diastole pada pasien hipertensi, yang berarti terdapat adanya pengaruh pada status tekanan darah setelah di berikan perlakukan terapi pijat (Udani 2016).

Beberapa penelitian lain juga menunjukkan bahwa pijat di lakukan secara teratur dan berkalikali dapat menurunkan tingkat kadar hormon stres pada seseorang, sehingga pungsi tubuh akan menjadi lebih baik, serta dapat menurunkan tingkat status tekanan darah systole, diastole dan denyut jantung (Setyawati and Emaliyawati 2018).

Ketika seseorang di lakukan pijat di bagian punggung juga dapat mempengaruhi pada system saraf superficial yang dapat menstimulasi pada bagian kulit serta mengontrol saraf secara teratur, sirkulasi darah pada otot-otot besar, sehingga menimbulkan respon relaksasi dan akan melancarkan aliran predaran pada tekanan darah (Andora 2015).

B. Perbedaan status tekanan darah pada kelompok intervensi pijat punggung dan kelompok kontrol.

Berdasarkan hasil analisa pada tabel 3 pada kelompok 1 dengan kelompok 2 di dapatkan hasil menunjukkan bahwa terdapat nilai $\mathrm{P}$-value $<0,05$ dapat disimpulkan bahwa terdapat perbedaan nilai signifikan terhadap status tekanan darah Sistole pada kelompok intervensi pijat punggung dengan kelompok kontrol. Pada status tekanan darah Diastole tidak mengalami perbedaan secara signifikan di dapatkan bahwa nilai $\mathrm{P}$-value $>0,05$.

Dapat di simpulkan bahwa berdasarkan analisis di atas terdapat perbedaan signifikan terhadap status tekanan darah Sistole, pada kelompok intervensi pijat punggung dan kelompok kontrol, sedangkan pada tingkat tekanan darah Diastole tidak mengalami perbedaan yang signifikan pada kelompok intervensi pijat punggung dan kelompok kontrol.

Hal tersebut berdasarkan penelitian sebelumnya mengatakan bahwa pijat adalah salah satu terapi komplementer yang di lakukan menggunakan tangan dan memanipulasi pada jaringan yang lunak dan bisa memberikan relaksasi pada setiap tubuh, selain itu memberikan efek pada tingkat stress seseorang, kecemasan, dan bisa memperlancar pada setiap aliran darah (Haryon,2016).

Kesimpulan tersebut juga di dukung dari studi literatur penelitian sebelumnya mengatakan bahwa orang yang di berikan dengan salah satu teknik relaksasi dapat menurunkan pada tingkat tekanan darah sitolik dan diastolik selain itu tingkat denyut jantung juga akan terjadi penurunan (Pratiwi, 2015).

Dalam penelitiannya Kim (2016) mengatakan bahwa pada responden yang di berikan perlakukan intervensi pijat punggung secara signifikan tingkat kecemasan seseorang akan berkurang dan menimbulkan respon nyaman serta menurunkan tingkat MAP pada sistolik dan diastolik.

Dapat di simpulkan dari analisis di atas tindakan intervensi pijat punggung pada pasien hipertensi dapat memberikan pengaruh terhadap status tekanan darah Sistole dan Diastole.

\section{KESIMPULAN}

Berdasarkan hasil penelitian dan pembahasan tentang "Pengaruh Pijat Punggung Terhadap Status Tekanan Darah Pada Pasien Hipertensi Di Wilayah Kerja Puskesmas Petaling menghasilkan beberapa simpulan:

1. Pijat punggung mempengaruhi status tekanan darah, dengan adanya penurunan tekanan darah systole maupun diastole, sebelum sesudah di berikan intervensi.

2. Terdapat perbedaan terhadap penurunan status tekanan darah systole pada ke dua kelompok dan tidak terdapat perbedaan pada penurunan status tekanan darah diastole, sebelum sesudah di berikan intervensi.

\section{SARAN}

Bagi perawat komunitas atau puskesmas

Di harapkan dengan adanya hasil penelitian ini dapat di gunakan atau di aplikasikan salah satu program sebagai intervensi terapi pendamping nonfarmakologis ataupun terapi tambahan dalam menangani pada pasien yang mengalami hipertensi.

\section{DAFTAR PUSTAKA}

Artiyaningrum, (2016) 'faktor-faktor yang berhubungan dengan kejadian hipertensi', Public Health Perspective Journal, pp. 1220. available at: https: //journal.unnes.ac.id/nju/index.php/phpj/ar tic le/view/7751/5395.

Haryono, R. et al. (2016) 'Pengaruh kombinasi pijat punggung dan dzikir terhadap tingkat stres pada penderita hipertensi', IV(1), pp. 12-21.

Helena, M., Cachoni, L. F., Costa-, J. R., Nascimento, P., \& Abreu, L. C. De.

http://jurnalilmiah.stikescitradelima.ac.id/index.php/JI Vol.4 No.2 Januari 2021 
(2015). Effects of a single-session massage

for sedentary older women with prehypertension: a pilot study. IMedPub Journals International, Vol. 8 No.(ISSN: 1755-7682 2015), 15.https://doi.org/10.3823/1757.

Juliantri, V., Nurfianti, et al. (2015) 'efektivitas massage ekstremitas terhadap perubahan tekanan darah pada pasien hipertensi di klinik pratama : pp. 247-265.

Kim, I., Kim, T., \& Ko, Y. (2016). The effect of a scalp massage on stress hormone, blood pressure, and heart rate of healthy female. The Journal of Physical Therapy Science Original, J. Phys. T, 2703-2707.

Nuraini, B. (2015) 'Risk factors of hypertension', J Majority, 4(5), pp. 10-19

Neupane, et al. (2014) 'Prevalence of hypertension in countries of South Asian Association for Regional Cooperation ; pp. 1 - $10 . \quad$ doi: 10.1097/MD.0000000000000074.

Pratiwi, L., Hasneli, Y., \& Ernawaty, J. (2015). Pengaruh Teknik Relaksasi Benson dan Membaca Al-Quran Terhadap Tekanan Darah Pada Penderita Hipertensi Primer. Journal Of Nursing, 2, 1-20.

Setyawati, A., \& Emaliyawati, E. (2018). Foot Massage Modification to Reduce Blood Pressure in Pregnant Woman with Preeclampsia, 6, 131-138.

Udani, G. (2016) 'Pengaruh Massase Pada Penderita Hipertensi Di UPTD Panti Tresna Werdha Lampung Selatan', Jurnal Kesehatan, 7(3),pp.503-507. Available at: https://www.poltekkestjk.ac.id/ejurnal/index.p h p/JK/article/view/236.

Zunaidi, A., Nurhayati, S., \& Prihatin, T. W. (2014). Pengaruh Pijat Refleksi Terhadap Tekanan Darah Pada Penderita Hipertensi Di Klinik Sehat Hasta Therapetika Tugurejo Semarang. Prosiding Konferensi Nasional Ii Ppni Jawa Tengah 2014,56-65. 